\title{
The Relationship Between Insomnia and Major Depressive Disorder: A Chicken and Egg Situation?
}

\author{
Mustafa Gulec ${ }^{1}$, Halil Ozcan², Elif Oral' ${ }^{1}$, Yavuz Selvi ${ }^{3}$, Adem Aydin ${ }^{3}$
}

\section{ÖZET:}

Uykusuzluk ve majör depresif bozukluk arasındaki bag̃lantı: Bir tavuk ve yumurta durumu mudur?

\begin{abstract}
Majör depresif bozukluk (MDB) çok yaygın, șiddetle güçsüz düșürücü ve sıklıkla da yineleyicidir. MDB'li bireylerin önemli bir kısmı uyku düzensizliklerinden yakınırlar. MDB aynı zamanda çeșitli uyku bozukluklu kitleler arasında fazla miktarda temsil edilmektedir. Uyku düzensizlikleri MDB'nin tipik özelliklerinden olsa da, böyle belirtiler bazen bir MDB döneminden önce ortaya çıkarlar. Uyku düzensizliḡi, özellikle de uykusuzluk ile MDB arasındaki çift yönlü ilișkiler, aralarındaki neden-sonuç bag̃lantılarının kurulmasını güçleștirmektedir. Uzunlamasına çalışmalar uykusuzlug̃u sürekli olarak yeni bașlangıçlı ya da yineleyici bir MDB gelişimi için bir risk etmeni olarak tanımlamışlar ve bu ilișki genç, orta yașlı ve hatta yașlı erișkinlerde gösterilmiștir. Araștırmalar uykusuzluk ve depresyon birlikteliḡinin aynı zamanda dönem șiddeti ve süresi yanında alevlenme oranlarını da artırarak MDB'nin seyrini etkiledig̃ini gözlemlemișlerdir. Ancak yakın tarihli çalıșmalar uykusuzluk için gerek ilaçla gerekse de ilaç dışındaki müdahalelerin MDB'yi uygun bir șekilde azaltabileceg̃i ve belki de önleyebileceg̃ini göstermișlerdir. Bu bulguların tümü birden uyku ile ilişkili belirtilerin ister bir MDB dönemi öncesinde, isterse de sırasında ve/veya sonrasında olsunlar, düzelme halinin sag̃lanması ve sürdürülmesinde önemli bir rol oynayabilecek büyük olasılıkla da deg̃iștirilebilir etmenler olduklarını ileri sürülmüștür.
\end{abstract}

Anahtar sözcükler: uykusuzluk, uyku, depresyon, depresif, bag̃lantı, ilişki

Journal of Mood Disorders 2012;2(1):28-33

\section{ABSTRACT:}

The relationship between insomnia and major depressive disorder: a chicken and egg situation?

Major Depressive Disorder (MDD) is highly prevalent, severely debilitating, and often recurrent. The majority of individuals with MDD experience sleep disturbances. MDD is also over-represented in populations with a variety of sleep disorders. Although sleep disturbances are typical features of MDD, such symptoms sometimes appear prior to an episode of MDD. The bidirectional association between sleep disturbance, especially insomnia and MDD, increases the difficulty of differentiating cause-and-effect relationship between them. Longitudinal studies have consistently identified insomnia as a risk factor for the development of a new-onset or recurrent MDD, and this association has been identified in young, middle-aged, and even older adults. Researches have also observed that the combination of insomnia and depression influences the trajectory of MDD, increasing episode severity and duration, as well as relapse rates. Fortunately, recent studies have demonstrated that both pharmacological and non-pharmacological interventions for insomnia may favourably reduce and possibly prevent MDD. Together, these findings suggest that sleep-related symptoms that are present before, during, and/or after a major depressive episode are potentially modifiable factors that may play an important role in achieving and maintaining remission of depression.

Key words: insomnia, sleep, depression, major depressive disorder, relationship, association

Journal of Mood Disorders 2012;2(1):28-33
${ }^{1} \mathrm{MD}$, Department of Psychiatry, Faculty of Medicine, Ataturk University, Erzurum-Turkey ${ }^{2} \mathrm{MD}$, Department of Psychiatry, Ministry of Health, Dr Zekai Tahir Burak Women's Health Training and Research Hospital, Ankara-Turkey ${ }^{3} \mathrm{MD}$, Department of Psychiatry, Faculty of Medicine, Yuzuncu Yil University, Van-Turkey

Yazısma Adresi / Address reprint requests to: Mustafa Gulec, Department of Psychiatry, Faculty of Medicine, Ataturk University, Erzurum-Turkey

Elektronik posta adresi / E-mail address: mustafagulec78@yahoo.com

Kabul tarihi / Date of acceptance: 8 Subat 2012/ February 8, 2012

Bag̃ıntı beyanı

M.G., H.O., E.O., Y.S., A.A.: Yazarlar bu makale ile ilgili olarak herhangi bir çıkar çatıșması bildirmemișlerdir.

Declaration of interest: M.G., H.O., E.O., Y.S., A.A.: The authors reported no conflict of interest related to this article.

\section{Major Depressive Disorder}

Major depressive disorder (MDD) is a severe, recurrent, and disabling medical illness that is highly prevalent worldwide and often associated with a negative impact on medical health, quality of life, and productivity (1). MDD, according to the DSM-IV-TR (American Psychiatric Association, 2000), is diagnosed by the presence of a constellation of symptoms including psychological (e.g. sadness), behavioural (e.g. suicidality), cognitive (e.g. concentration), and somatic/physical symptoms (e.g. sleep, energy, psychomotor, and appetite disturbances). The lifetime risk of developing MDD is as high as $25 \%$ in women and $12 \%$ in men (2). According to the WHO, depressive disorders are the fourth leading cause of disability-adjusted life years worldwide, and by year 2020 they are estimated to be the second only to ischemic heart disease (3). A recent analysis on the effect of mood disorders on work performance conducted by Kessler and colleagues revealed that MDD is associated with 27.2 lost work-days per ill worker per year (4). This is of great concern and constitutes a major public health 
issue, since the incidence of depression is expected to increase as a result of prolonged life expectancy and social and demographic changes (5).

\section{Definitions of Specific Terms used in Evaluating and Treating Major Depressive Disorder Clinically}

\section{Response}

The American College of Neuropsychopharmacology (ACNP) Task Force agreed with the widely held concept that response represents a clinically meaningful degree of reduction in depressive symptoms, and restated the commonly accepted criterion of a $\geq 50 \%$ reduction in baseline severity, assessed by a symptom severity rating scale (6).

\section{Full remission}

Similarly, the recommendation of the ACNP Task Force is to use a score of $\leq 7$ or $\leq 5$ on the HAMD- 17 scale as criteria for full remission (6). Full remission is obtained where clinical improvement is such that the patient becomes almost asymptomatic.

\section{Partial remission}

Partial remission is defined as a period of time with some improvement of symptoms, but not of enough magnitude as to achieve full remission, and with the persistence of some residual symptoms. This state corresponds to a score of 8 to 15 on the HAMD-17 (7).

\section{Recovery}

Recovery from depression was defined as a period of at least 2 months during which there were no significant symptoms of depression, which was defined operationally as 8 consecutive HAMD-17 scores of 7 or less within 6 months of beginning medical treatment and subsequent confirmation of the absence of major depression by diagnostic re-evaluation (8).

\section{Relapse}

Relapse was viewed as a return of the index major depressive episode (MDE) following the onset of full or partial remission but before fulfilling the criteria for recovery. So, relapse can be defined as the re-appearance or aggravation of symptoms to score 18 or more on the HAMD-17 scale for at least 2 consecutive weeks in the partial or full remission period (6).

\section{Recurrence}

Recurrence referred to the development of a new MDE following the recovery. In other words, a new MDE which fully met diagnostic criteria must emerge during the recovery period for the term of recurrence according to The ACNP Task Force (6).

\section{The Significance of Full Remission and The Role of Residual Symptoms}

In recent years, the ACNP Task Force has established remission as the goal of treatment for patients with MDD (6). The most widely used criterion for remission is a Hamilton Rating Scale for Depression (HAMD-17) score of $\leq 7$, which corresponds to a HAMD-7 score of $\leq 3$ (9). However, the recommendation of the ACNP Task Force is to use a score of $\leq 7$ or $\leq 5$ on the HAMD-17 scale as criteria for remission (6). Furthermore, although the goal of treating MDD is to achieve full remission, it is common for many patients to continue suffering from residual symptoms after they respond to treatment (10). The consequence of not achieving remission is that patients with residual depressive symptoms (i.e., partial- and nonresponders to antidepressant medications) have an increased risk for MDD and a shorter time to relapse of symptoms (3). Increasingly, researchers and clinicians have advocated the importance of treating residual symptoms and of exploring their neurobiological basis to develop better treatment options and to improve MDD outcome (11).

\section{The Importance of Sleep Disturbance as a Residual Symptom}

Whether all previously mentioned diagnostic depressive symptoms weigh equally with regards to their adverse impact on functioning, morbidity, mortality, and treatment outcome or whether some symptoms are more 
relevant than others remain, as of yet, undetermined. However, several studies published to date suggest that sleep disturbance may represent such a symptom that weighs more heavily with regards to its adverse impact on a number of outcomes (12). For instance, complaints of poor sleep are reported in up to $90 \%$ of people with diagnosed depression $(13,14)$. Among the residual symptoms, disturbed sleep is also the most prevalent (15). Nierenberg and his colleagues assessed the prevalence of residual symptoms in a sample of 215 patients taking open-label fluoxetine $20 \mathrm{mg}$ for 8 weeks; of the original sample, 108 achieved remission (HAMD-17 score $\leq 7$ ), yet $44 \%$ continued to complain of problems with sleep (16). Of all sleep-related complaints, insomnia (and resultant daytime sleepiness) is the most frequent (5). In a recent study the patients in remission after completing at least 20 weeks of therapy, $22 \%, 26 \%$, and $17 \%$ still suffered from initial insomnia, middle insomnia, and terminal insomnia, respectively (17). More than $40 \%$ of patients reported symptoms of fatigue and sleepiness/sedation even they were inpartial or full remission (18).

\section{The Consequences of Insomnia in Terms of Major Depressive Disorder in Presently Healthy Individuals}

Insomnia and depression are also bi-directionally related (19). So, insomnia is a risk factor for developing depression and residual insomnia symptoms after a major depressive episode increase the risk of relapse and recurrence. In the National Institute of Mental Health Epidemiologic Catchment Area study sample, individuals with persistent insomnia (present at both baseline and 1-year follow-up) were much more likely to develop a new depressive episode at follow-up compared with individuals whose insomnia resolved by follow-up (20). Subsequent analyses revealed that $14 \%$ of those who had insomnia at the first interview had developed new major depressive disorder a year later and those with sleep problems had the highest relative odds (7.6 times) of developing a new-onset major depressive episode during the next year compared with those without sleep problems (21). The data have been augmented by several more recent reports of increased risk. In a longitudinal study of 979 young adults, insomnia increased the relative risk for depression fourfold over a 3-year period, even after controlling for baseline depression symptoms (22). One study followed over 1000 male medical students for a median of 34 years (range 1-45). The physicians in this prospective study who had complained of insomnia during medical school in the 1950s and 1960s were twice as likely to have developed depression at follow-up in 1990s (23).

The association between insomnia and depression has also been reported in more recent studies. Sleep disturbance appears to be one of the important risk factors for depression among elderly community subjects (24). Another review, consisting of 8 longitudinal epidemiological studies, showed that the presence of insomnia symptoms at baseline significantly predicted an increased risk of depression at follow-up 1-3 years later (25). There was a 3-fold higher risk of new depression if subjects had reported one sleep problem occurring "on most nights" a year earlier in a questionnaire survey of adults over 18 in the UK (26). The longitudinal study of Buysse and his colleagues showed the increased risk of subsequent depression among individuals with insomnia (27). Similarly, LeBlanc et al. found that compared to good sleepers and insomnia symptoms incident cases, the insomnia syn-drome incident cases presented a premorbid psychological vulnerability to insomnia, characterized by higher depressive and anxiety symptoms (28). In light of these studies, it is possible to conclude that insomnia may mediate the development of depression. If this would be true, treating insomnia may have important implications for preventing the onset or recurrence of depression.

\section{The Risk of Ongoing or Re-Emerging Insomnia for Subsequent Relapse or Recurrence of Major Depressive Episode}

As mentioned, residual symptoms are predictors of relapse or recurrence and may be associated with residual psychosocial impairment (29). This relationship also was demonstrated in previous studies. Continued insomnia following the acute phase of antidepressant therapy poses a significant risk for relapse. For instance, $67 \%$ of patients with persistent insomnia at the end of treatment with nortriptyline and interpersonal psychotherapy relapsed within one year after switching to placebo pill. In contrast, $90 \%$ of the patients with improved sleep quality remained well, compared to $33 \%$ of patients with persistent 
insomnia who remained well (30). Residual symptoms of insomnia after a major depressive episode also increase the risk of recurrence. So, there are indications that insomnia may be a first-occurring prodromal symptom in previously depression-remitted persons. In one small study of patients with recurrent MDD who were currently in remission for at least 4 weeks, progressively greater levels of subjective sleep disturbance preceded the recurrence of a depressive episode (31).

The association between insomnia and major depressive relapse or recurrence has also been reported in more recent studies $(32,33,34)$. Armitage stated that persistent sleep problems, insomnia specifically, elevate the risk of relapse and recurrence, as well as the need for augmenting medications (32). Additionally, Ohayon and Roth showed that insomnia appeared before $(>40 \%)$ or in the same time $(>22 \%)$ than mood disorder symptoms in most cases of mood disorders (33). So, chronic insomnia can be a residual symptom of a previous mood disorder and put these subjects to a higher risk of relapse. Subjective sleep problems, including insomnia, were also found to be predictors of early recurrence in a study of "remitted" patients maintained on an SSRI and psychotherapy (34). Very recently, we have assessed the frequency and types of ongoing or re-emerging subjective insomnia symptoms and their relationship to subsequent depressive relapse or recurrence in a group of full/partial remitters or recoverers (35). Majority of the participants had subjective sleep disturbance, insomnia prior to relapse or recurrence. Repeated measures of ANOVA were used to evaluate changes in scores of depression and sleep scales over time between recurred and non-recurred groups. Differences between means were calculated with post hoc Bonferroni comparison test. The changes in scores of entire clinical scales over time between recurred and non-recurred groups were statistically significant. As a consequence, our data suggest that patients who suffer recurrence exhibit greater levels of sleep disturbance several weeks prior to recurrence and the subjective sleep complaints may precede the series of symptoms that comprise the syndrome of major depression. These findings are consistent with the studies of previously mentioned authors. The data from these studies provide strong evidence that self-reported sleep disturbance not only can predict incidence of MDD in the longitudinal course, but also represents the vulnerability to MDD. Therefore, regular monitoring of sleep status may allow for treatment intervention prior to the development of the full clinical syndrome. Such early intervention may delay, diminish the intensity of, or possibly prevent recurrent depressive episodes. Insomnia-specific interventions (e.g., hypnotherapeutic drugs, sleep hygiene, and cognitive behavioural psychotherapy) may therefore lead to remission that is more stable, extending the time between depressive episodes and possibly lowering relapse and recurrence rates.

Furthermore, we have encountered similar results with bipolar depression. Sleep disturbance is also a common feature during depressive episodes in bipolar disorder. Even the interepisode bipolar individuals exhibit greater sleep disturbance than the healthy controls $(36,37)$. Recently, Sylvia and her colleagues (38) investigated prevalence of such symptoms among euthymic bipolar patients and their association with risk for depressive episode recurrence. They found that sleep disturbance at study entry was significantly associated with risk for depressive episode recurrence. Also, disturbed sleep appears to be an early symptom of the first mood episode of bipolar disorder (39). Additionally, sleep disturbance may be associated with a more severe course of illness. In line with this inference, Gruber et al. (40) demonstrated that greater sleep variability was associated with increased depression severity in bipolar disorder. And, more variable sleep efficiency was also found to be associated with more lifetime depressive episodes (41). All these suggest that sleep disturbance is an important prodromal symptom of bipolar disorder and should be considered a target for pharmacological and/or psychosocial maintenance treatment.

\section{CONCLUSIONS}

MDD has been increasingly prevalent worldwide. It has severe consequences and is associated with increased rates of disability, morbidity, and mortality. Despite numerous therapeutic options and recommendations of current guidelines, a great number of depressed patients cannot achieve full remission. So, majority of the patients continue to suffer from residual symptoms even after they respond to treatment partially. In addition, despite good short-term outcomes, long-term therapeutic results still remain disappointing and are associated with a poor 
prognosis, raising significant public health concerns. Impaired sleep, especially insomnia may be at least partly responsible for this problem. Very close relationships between MDD and sleep disorders have been observed. In particular, residual symptoms of sleep disturbance in a remitted patient may predict a relapse or recurrence of the disease. However, most currently available antidepressants do not always take into consideration the sleep disturbances of depressed patients; some agents long used in clinical practice (e.g., SSRIs) even appear to worsen them by their sleep-disrupting properties. But some other new medications (e.g., agomelatine) were shown to relieve early sleep disturbance in addition to alleviating other depression-related symptoms. This

\section{References:}

1. Machado-Vieira R, Salvadore G, Luckenbaugh DA, Manji HK, Zarate CA Jr. Rapid onset of antidepressant action: a new paradigm in the research and treatment of major depression. J Clin Psychiatry 2008; 69: 946-958.

2. American Psychiatric Association, 2000. Diagnostic and Statistical Manual of Mental Disorders (DSM-IV-TR). American Psychiatric Association, Washington, DC.

3. Kurian BT, Greer TL, Trivedi MH. Strategies to enhance the therapeutic efficacy of antidepressants: targeting residual symptoms. Expert Rev Neurother 2009; 9: 975-984.

4. Kessler RC, Akiskal HS, Ames M, Birnbaum H, Greenberg P, Hirschfeld RMA, Jin R, Merikangas KR, Simon GE, Wang PS. Prevalence and effects of mood disorders on work performance in a nationally representative sample of U.S. workers. Am J Psychiatry 2006; 163: 1561-1568.

5. Mendlewicz J. Sleep disturbances: core symptoms of major depressive disorder rather than associated or comorbid disorders. World J Biol Psychiatry 2009; 10: 269-275.

6. Rush AJ, Kraemer HC, Sackeim HA, Fava M, Trivedi MH, Frank E, Ninan PT, Thase ME, Gelenberg AJ, Kupfer DJ, Regier DA, Rosenbaum JF, Ray O, Schatzberg AF. Report by the ACNP Task Force on response and remission in major depressive disorder. Neuropsychopharmacol 2006; 31: 1841-1853.

7. Mendlewicz J. Towards achieving remission in the treatment of depression. Dialogues Clin Neurosci 2008; 10: 371-375.

8. Lustman PJ, Clouse RE, Nix BD, Freedland KE, Rubin EH, McGill JB, Williams MM, Gelenberg AJ, Ciechanowski PS, Hirsch IB. Sertraline for prevention of depression recurrence in diabetes mellitus: a randomized, double-blind, placebo-controlled trial. Arch Gen Psychiatry 2006; 63: 521-529.

9. McIntyre R, Kennedy S, Bagby RM, Bakish D. Assessing full remission. J Psychiatr Neurosci 2002; 27: 235-239. positive impact should promote compliance with medication and psychological treatments and increase daytime performance and overall functioning. The complete remission of MDD appears therefore to depend on the relief of sleep disturbance, a core symptom of MDD that should be taken into consideration and treated early in depressed patients.

In summary, there are evidence that sleep strongly influences both the development and trajectory of depression and impacts episode frequency, severity and duration in depression. Hence sleep-related symptoms may be important and modifiable risk factors to prevent depression and/or achieve and maintain remission in treatment of depression.

10. Trivedi MH, Rush AJ, Wisniewski SR, Nierenberg AA, Warden D, Ritz L, Norquist G, Howland RH, Lebowitz B, McGrath PJ, ShoresWilson K, Biggs MM, Balasubramani GK, Fava M; STAR*D Study Team. Evaluation of outcomes with citalopram for depression using measurement-based care in STAR*D: implications for clinical practice. Am J Psychiatry 2006; 163: 28-40.

11. Trivedi MH, Hollander E, Nutt D, Blier P. Clinical evidence and potential neurobiological underpinnings of unresolved symptoms of depression. J Clin Psychiatry 2008; 69: 246-258.

12. Yang H, Sinicropi-Yao L, Chuzi S, Youn SJ, Clain A, Baer L, Chen Y, McGrath PJ, Fava M, Papakostas GI. Residual sleep disturbance and risk of relapse during the continuation/maintenance phase treatment of major depressive disorder with the selective serotonin reuptake inhibitor fluoxetine. Ann Gen Psychiatry 2010; 9: 52-56.

13. Tsuno N, Besset A, Ritchie K. Sleep and depression. J Clin Psychiatry 2005; 66: 1254-1269.

14. Almeida OP, Pfaff JJ. Sleep complaints among older general practice patients: association with depression. Br J Gen Pract 2005; 55: 864-866.

15. Nutt D, Wilson S, Paterson L. Sleep disorders as core symptoms of depression. Dialogues Clin Neurosci 2008; 10: 329-336.

16. Nierenberg AA, Keefe BR, Leslie VC, Alpert JE, Pava JA, Worthington JJ 3rd, Rosenbaum JF, Fava M. Residual symptoms in depressed patients who respond acutely to fluoxetine. J Clin Psychiatry 1999; $60 ; 221-225$.

17. Carney CE, Segal ZV, Edinger JD, Krystal AD. A comparison of rates of insomnia symptoms following pharmacotherapy or cognitivebehavioral therapy for major depressive disorder. J Clin Psychiatry 2007; 68: 254-260.

18. Fava M, Graves LM, Benazzi F, Scalia MJ, Iosifescu DV, Alpert JE, Papakostas GI. A cross-sectional study of the prevalence of cognitive and physical symptoms during long-term antidepressant treatment. J Clin Psychiatry 2006; 67: 1754-1759. 
19. Franzen PL, Buysse DJ. Sleep disturbances and depression: risk relationships for subsequent depression and therapeutic implications. Dialogues Clin. Neurosci 2008; 10: 473-481.

20. Ford DE, Kamerow DB. Epidemiological study of sleep disturbances and psychiatric disorders: an opportunity for prevention? JAMA 1989; 262 : 1479- 1484 .

21. Eaton WW, Badawi M, Melton B. Prodromes and precursors: epidemiologic data for primary prevention of disorders with slow onset. Am J Psychiatry 1995; 152: 967-972.

22. Breslau N, Roth T, Rosenthal L, Andreski P. Sleep disturbance and psychiatric disorders: a longitudinal epidemiological study of young adults. Biol Psychiatry 1996; 39: 411-418.

23. Chang PP, Ford DE, Mead LA, Cooper-Patrick L, Klag MJ. Insomnia in young men and subsequent depression. The Johns Hopkins Precursors Study. Am J Epidemiol 1997; 146: 105-114.

24. Cole MG, Dendukuri N. Risk factors for depression among elderly community subjects: a systematic review and metaanalysis. Am J Psychiatry 2003; 160: 1147-1156.

25. Riemann D, Voderholzer U. Primary insomnia: a risk factor to develop depression? J Affect Disord 2003; 76: 255-259.

26. Morphy H, Dunn KM, Lewis M, Boardman HF, Croft PR. Epidemiology of insomnia: a longitudinal study in a UK population. Sleep 2007; 30: 274-280.

27. Buysse DJ, Angst J, Gamma A, Ajdacic V, Eich D, Rössler W. Prevalence, Course, and Comorbidity of Insomnia and Depression in Young Adults. Sleep 2008; 31: 473-480.

28. LeBlanc M, Mérette C, Savard J, Ivers H, Baillargeon L, Morin CM. Incidence and risk factors of insomnia in a population-based sam $\neg$ ple. Sleep 2009; 32: 1027-1037.

29. Möller HJ. Outcomes in major depressive disorder: The evolving concept of remission and its implications for treatment. World J Biol Psychiatry 2008; 9: 102-114.

30. Reynolds CF, Frank E, Houck PR, Mazumdar S, Dew MA, Cornes C, Buysse, Begley A, Kupfer DJ. Which elderly patients with remitted depression remain well with continued interperson $\neg$ al psychotherapy after discontinuation of antidepressant medica $\neg$ tion? Am J Psychiatry 1997; 154: 958-962.
31. Perlis ML, Giles DE, Buysee DJ, Tu X, Kupfer DJ. Self-reported sleep disturbance as a prodromal symptom in recurrent depres $\neg$ sion. J Affect Disord 1997; 42: 209-212.

32. Armitage R. The effects of antidepressants on sleep in patients with depression. Can J Psychiatry 2000; 45: 803-809.

33. Ohayon MM, Roth T. Place of chronic insomnia in the course of depressive and anxiety disorders. J Psychiatr Res 2003; 37: 9-15.

34. Dombrovski AY, Mulsant BH, Houck PR, Mazumdar S, Lenze EJ, Andreescu C, Cyranowski JM, Reynolds CF 3rd. Residual symptoms and recurrence during maintenance treatment of latelife depression. J Affect Disord 2007; 103: 77-82.

35. Gulec M, Selvi Y, Boysan M, Aydin A, Besiroglu L, Agargun MY. Ongoing or re-emerging subjective insomnia symptoms after full/ partial remission or recovery of major depressive disorder mainly with the selective serotonin reuptake inhibitors and risk of relapse or recurrence: a 52-week follow-up study. J Affect Disord 2011; 134: 257-265.

36. Brill S, Penagaluri P, Roberts RJ, Gao Y, El-Mallakh RS. Sleep disturbances in euthymic bipolar patients. Ann Clin Psychiatry 2011; 23: 113-116.

37. Talbot LS, Stone S, Gruber J, Hairston IS, Eidelman P, Harvey AG. A test of the bidirectional association between sleep and mood in bipolar disorder and insomnia. J Abnorm Psychol 2011; [Epub ahead of print].

38. Sylvia LG, Dupuy JM, Ostacher MJ, Cowperthwait CM, Hay AC, Sachs GS, Nierenberg AA, Perlis RH. Sleep disturbance in euthymic bipolar patients. J Psychopharmacol 2011; [Epub ahead of print]

39. Ritter PS, Marx C, Bauer M, Leopold K, Pfennig A. The role of disturbed sleep in the early recognition of bipolar disorder: a systematic review. Bipolar Disord 2011; 13: 227-237.

40. Gruber J, Miklowitz DJ, Harvey AG, Frank E, Kupfer D, Thase ME, Sachs GS, Ketter TA. Sleep matters: sleep functioning and course of illness in bipolar disorder. J Affect Disord 2011; 134: 416-420.

41. Eidelman P, Talbot LS, Gruber J, Harvey AG. Sleep, illness course, and concurrent symptoms in inter-episode bipolar disorder. J Behav Ther Exp Psychiatry 2010; 41: 145-149. 